\title{
Status of non-cocoa tree species in cocoa multistrata systems of southern Cameroon
}

\author{
BIDZANGA NOMO ${ }^{1 *}$, Birang A. MADONG ${ }^{1}$ and Fergus SINCLAIR ${ }^{2}$ \\ ${ }^{I}$ Institut de la Recherche Agricole pour le Developpement, P.O. Box 2123, Messa, Yaoundé, Cameroon. \\ ${ }^{2}$ School of Agricultural and Forest Sciences SAFS University of Wales Bangor UK. \\ *Corresponding author,E-mail: n_bidzanga@yahoo.fr
}

\begin{abstract}
Investigations to assess the status of non-cocoa tree species in the cocoa systems of southern Cameroon were carried out in four contrasting locations, distinguished by ecology, population density and land use intensity. One set of inventory was done in each of the 20 selected cocoa farms with an average surface area of 1.4 ha in every location. The inventory was carried out over $25 \%$ of each farmland following a gradient directed transect method. Within each cocoa farm, only indigenous tree species and shrubs with the capacity of being transformed into tree species were considered. Our findings showed that there was in total 165 different non-cocoa tree species in the 80 cocoa fields observed. The number of shared species between locations was relatively high (54\% to $74 \%$ ). Frequency distribution of the number of species classified by the number of farms where they were found showed that most species were fairly rare. Tree species richness varied widely between cocoa farms within locations. These findings suggest the need for the various stakeholders of the sector to take appropriate actions to protect endangered species of ecological and economical importance in order to enhance the sustainability of these systems.

() 2008 International Formulae Group. All rights reserved.
\end{abstract}

Keywords: Species diversity, cocoa systems, land use, sustainability.

\section{INTRODUCTION}

A large number of farmers in southern Cameroon have a long tradition of maintaining tree biodiversity in their cocoa fields. In this regard, cocoa systems in southern Cameroon are ranked amongst the best examples in Africa of seemingly permanent agriculture that preserves a forestlike environment and some of its biodiversity (Ruf and Schroth, 2004). Zapfack et al. (2002) ranked cocoa systems in southern Cameroon fourth after the primary forest, the secondary forest and old fallows, as systems that preserve tree biodiversity in Cameroon. The diversity and complexity of cocoa systems form the basis of important ecological functions that maintain their productivity and still remain environmentally friendly. Products harvested or collected from the noncocoa tree components such as, indigenous fruits, timber, spices, medicinal or fuel wood, also contribute enormously to the livelihoods of the local communities.

However, recent studies (Duguma et al., 2002; Sonwa et al., 2004; Bidzanga Nomo, 2005) revealed that these systems are becoming ecologically less stable and productive than they were some years back. Indeed, natural death of plant species is increasingly leading to the disappearance of some species. In addition, the structural adjustment reforms following the economic crisis of the early 1980s led to the suppression by government of subsidies to the fertiliser and pesticide sub-sectors; the liberalisation of the price of cocoa and the overall disengagement of government from the cocoa sector (Duguma et al., 2002; Coulibaly et al., 2004). Local farmers responded to this overall economic shock by increasingly introducing 
fruit trees, some domesticated trees of economic importance or food crops into their cocoa fields at the expense of indigenous species, irrespective of their ecological importance. This in turn had negative effects on the ecological equilibrium of these systems and by extension on their sustainability and productivity.

Southern Cameroon that constitutes the core study area is part of the Congo basin rainforest, whose borders encompass the world's largest area of contiguous rainforest. Biodiversity in this region is threatened by the high rate of deforestation that has occurred over recent years. The annual rate of deforestation is estimated at $6 \%$, with about 129000 ha of the remaining $19 \mathrm{M}$ ha of closed canopy forest lost annually (FAO, 1999). Most of this deforestation (85\%) is attributed to smallholder agricultural practices whereby extensive slash-and-burn techniques are used for the creation of new farms (Gockowski et al., 1998; Kotto-Same et al., 2000). The low productivity of agriculture, coupled with rapid population growth, results in a continual decrease of the forest margin (Gockwoski et al., 1998a).

This paper focuses on the state of noncocoa tree species within cocoa fields in four contrasting locations of the main cocoa producing basins of southern Cameroon distinguished by ecology, population density and land use intensity. Its particular interest is on the estimation of the composition, abundance and distribution of non-cocoa tree species that may contribute to a better understanding of the actual status of noncocoa tree species within the cocoa systems of the study area. An underlying thought is to enhance the role of a seemingly permanent agricultural system that preserves a forest-like environment and some of its biodiversity (Ruf and Schroth, 2004).

\section{MATERIALS AND METHODS \\ The study area}

Four locations of the cocoa production basin of southern Cameroon were selected on the basis of their ecology, population density and land use intensity. Akok in the southernmost zone is characterised by large stretches of primary rainforest $(59 \%$ of land cover) (Gockowsky et al., 1998; Ngobo 2002), low land use intensity and low population density ( 2 to 15 inhabitants per $\mathrm{km}^{2}$ ). Awae and Nkongmesse locations are both situated in a strongly degraded rainforest area, but are distinguished by land use intensity and population density. The Nkongmesse location has an average population density of 80 inhabitants per $\mathrm{km}^{2}$ and high land use intensity with only $4 \%$ of the land covered by primary forest (Gockowsky et al., 1988). Land shortage is on the rise and fallow lengths are being shortened as a result of population pressure. In the Awae location, the population density ranges from 13 to 41 inhabitants per $\mathrm{km}^{2}$ and the land use intensity is moderate. The secondary forest is gradually disappearing with fallow periods varying from 5 to 10 years for mixed crop food fields. Ndikinimeki, the fourth location is situated at the forestsavannah transition zone in the northernmost part of the study area. The vegetation is strongly influenced by topography, with forest galleries along the river sides, bottomlands and some ravines. The land-use intensity is high because of insufficient arable land and high population density (Figure 1).

Soils in the study area fall within the FAO grouping of ferralsols, which are the largest soil class in the tropics. Physical and hydraulic characteristics of these soils reveal, by their variation in the ferralitic field, the existence of a zonal arrangement due to climate and human activity. The south which is moist and covered with evergreen forest, stands in contrast to the north, which is drier and covered with savannah and forest galleries (Humble, 1974). Soil profiles of the domain present minor differences in terms of mineralogy and structure. The surface layers are generally low in clay content, and organic matter is not evenly distributed. The cation exchange capacity (CEC) of these soils is generally low due to their high rate of leaching, indicating low fertility (Humbel, 1974, van Ranst, 1983). From the moist zones in the south to the more contrasted zones in the north, the apparent soil modifications lie in the change of colour from yellow to red.

Climate in the study area falls into the tropical type. Locally, this climate is characterised by a bimodal rainfall pattern. Annual rainfall varies from $1350 \mathrm{~mm}$ to the north of Yaoundé to $1900 \mathrm{~mm}$ to the southmost zone of the study area (Gockowski et al., 1998a). 


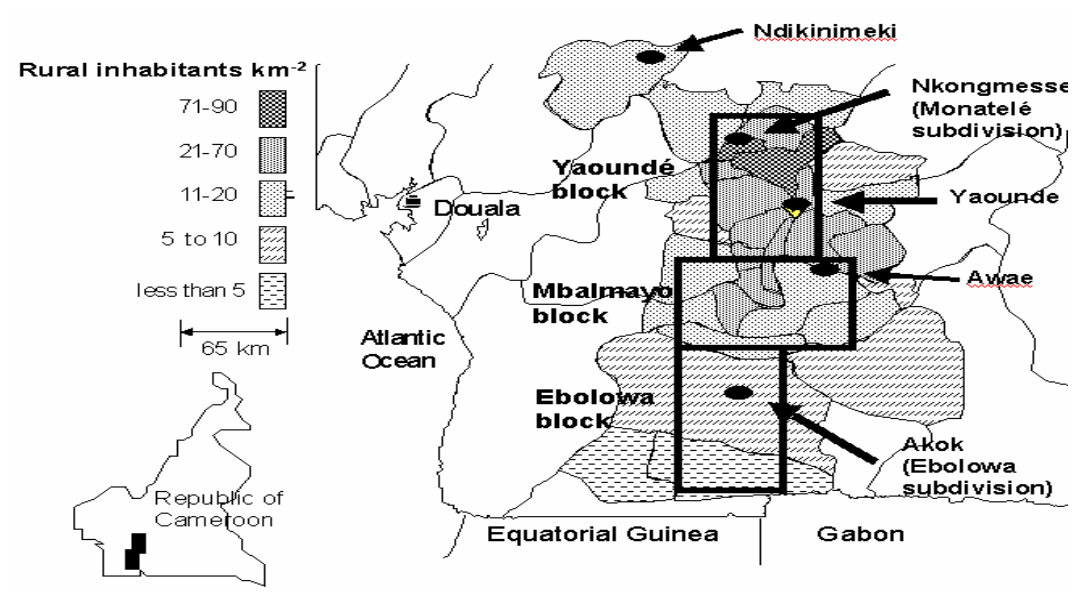

Figure 1: Geographical location of the four study sites

The longer rainy season occurs during the period March-June, although more rain falls within the shorter period of SeptemberNovember. The longer dry period in the year extends from December to February, while the period July to August, though dry, has sporadic rainfall. In this period, the temperatures are lowest and the air saturation relatively high.

\section{Tree species inventory method}

An inventory based on the composition of the non-cocoa tree species was done in twenty cocoa farms in each of the four study locations. One round of inventory was carried out over $25 \%$ of each farmland area following a gradient directed transect method. Given the median cocoa farm size in the study area that stands at 1.4 ha, 25\% surface area was generally above the $40 \mathrm{~m} \times 5 \mathrm{~m}$ area proposed by Gillison and Brewer (1985), for estimating the diversity of the study milieu whatever the ecosystem. Within a cocoa farm, only indigenous tree species and shrubs with the capacity of transforming into tree species if not suppressed during farm maintenance activities were recorded. Common exotic species were not recorded because the purpose of the study was to assess the value of multistrata cocoa systems for the conservation of indigenous species.

A taxonomist recorded the entire tree species counted in the inventory, with the assistance of the farm owner for the identification of the local names of species'. References from various authors (Vivien and Faure, 1985, 1996; Souane Thicakul, 1985; Lebrun and Stork, 1991, 1992, 1995, 1997) were also used to consolidate the information collected.

\section{Data statistical analysis}

The sequential accumulation of tree species in a single cocoa field, and further, the pooling of cocoa fields from a single location that produce species sample-based accumulation curves for each study location were computed by EstimateS programme, version 6.0b1 (Colwell, 1997) that uses the Mao Tau equation.

$$
\mathrm{S}_{\mathrm{obs}}=\sum_{\mathrm{J}=1}^{\mathrm{H}} \mathrm{Sj}
$$

Where $S_{\mathrm{obs}}$ is the observed richness in the cocoa fields of a given location. $\mathrm{Sj}$ stands for the number of tree species found in exactly $\mathrm{j}$ cocoa fields of a study location, which has a total of $H(20)$ cocoa fields. Thus, $S_{1}$ is the number of tree species found in precisely 1 cocoa field, $S_{2}$ is the number of tree species found in precisely 2 cocoa fields, and so on.

This was complemented by frequency distributions of species occurrence and numbers of species on farms.

Estimation of the percentage of tree species coincidence between the study locations was done by calculating the 
Sorensen Index (CCs, Equation 1) of floristic similarity (Brower and Zar, 1977).

$$
\mathrm{CCs}=\frac{2 \mathrm{c}}{\mathrm{a}+\mathrm{b}}
$$

Where a stands for species number in location 1 , b stands for species number in location 2 , and c stands for number of shared species in both locations.

The results multiplied by 100 correspond to the percentage of tree species coincidence.

Frequency distributions of the number of tree species classified by the number of farm on which they were found and the number of farms by the number of species found on them where computed using the empirical data of the inventory.

\section{RESULTS}

\section{Species diversity}

Empirical data (Table 1) of the inventory of non-cocoa tree species used to compute some tree diversity estimators (sample-based accumulation curves for the four study locations and the Sorensen Index) and frequency distributions of trees showed that there were in total 165 different noncocoa trees in the cocoa systems of the study locations.

Considering the Sorensen Index (CCs) (Table 2), the proportion of non-cocoa tree species coincidence was relatively high amongst the locations of Akok, Awae and Nkongmesse (70 to $74 \%$ of the species recorded). The highest similarities in species comparison occurred between Nkongmesse and Awae, and Nkongmesse and Akok (74\%). In contrast, the similarities were less between these locations and Ndikinimeki (54 to 62\%).

\section{Variability in species composition}

The figures on the variability in species composition indicated that the tree species number per farm was higher at Nkongmesse and ranged from 15 to 46 species, with a mean value of 28.20, as compared to Akok and Awae locations, which belong to similar ecozones, and where they ranged from 7 to 33 species with a mean value of 19.30 , and 7 to 35 species with a mean value of 20.15, respectively. The lowest number of tree species was observed at Ndikinimeki (mean value estimated at 15 with a range of 9 to 27 species). This was expected due to its ecological environment. The difference in variability of species richness amongst locations was not large (standard error ranging from 1.29 to 1.93). The sample-based species accumulation curves (Figure 2) confirmed the generally higher species richness of the Nkongmesse farms and the lower number of species at Ndikinimeki, whilst the curves of Akok and Awae almost overlap.

Tree species abundance on farms and number of species per farm

The frequency distribution of the number of species classified by the number of farms where they were found showed that most species were fairly rare (found on few farms). Indeed, 29 to 73 of the non-cocoa tree species inventoried in the cocoa systems of southern Cameroon, representing 53\% to $67 \%$ of the trees according to location, were found on less than five farms. More species were found on more cocoa farms at Nkongmesse, thus indicating a more important degree of tree diversity conservation in that location, as compared to Akok, Awae and Ndikinimeki.

The frequency distributions of farms classified by number of species found on them show that, except for Nkongmesse where the distribution is fairly normal, most cocoa farms in the other study locations have a low number of species (Figure 3).

Table 1: Empirical data used to compute some tree diversity estimates.

\begin{tabular}{llll}
\hline Locality & Species & Samples & References \\
\hline Akok & 108 & 20 & Sonwa et al. 2002 \\
Awae & 108 & 20 & Sonwa et al. 2002 \\
Nkongmesse & 109 & 20 & Sonwa et al. 2002 \\
Ndikinimeki & 55 & 20 & Bidzanga Nomo et al. 2004 \\
\hline
\end{tabular}




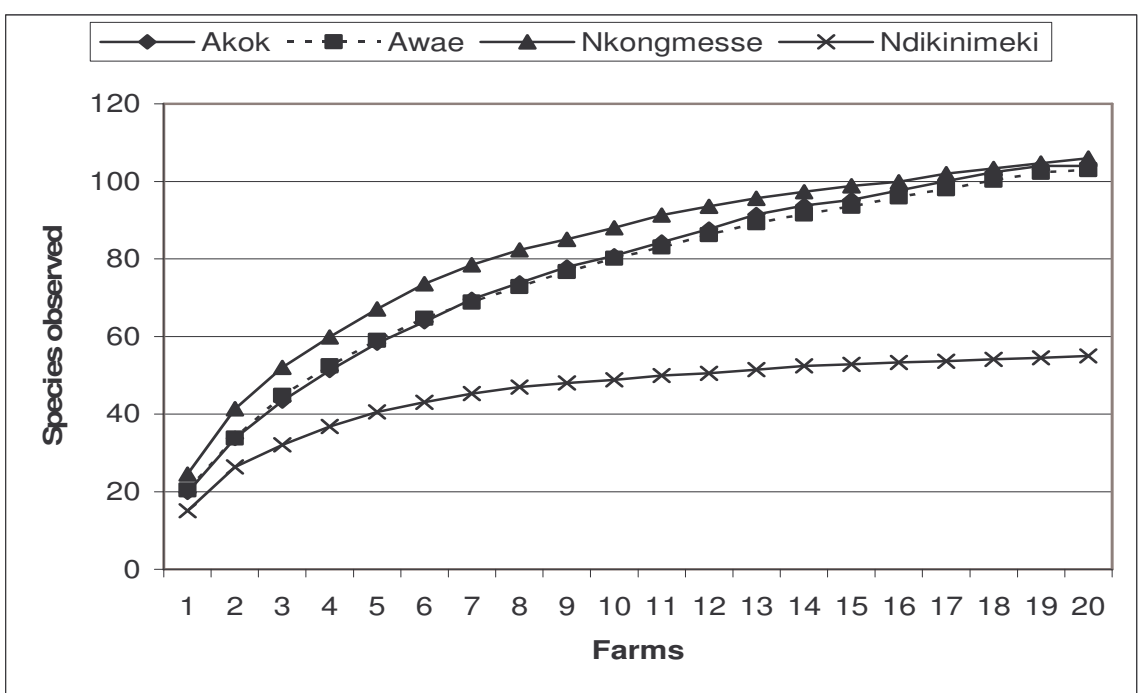

Figure 2: Tree species sample-based accumulation curves of 20 cocoa farms for each study location.

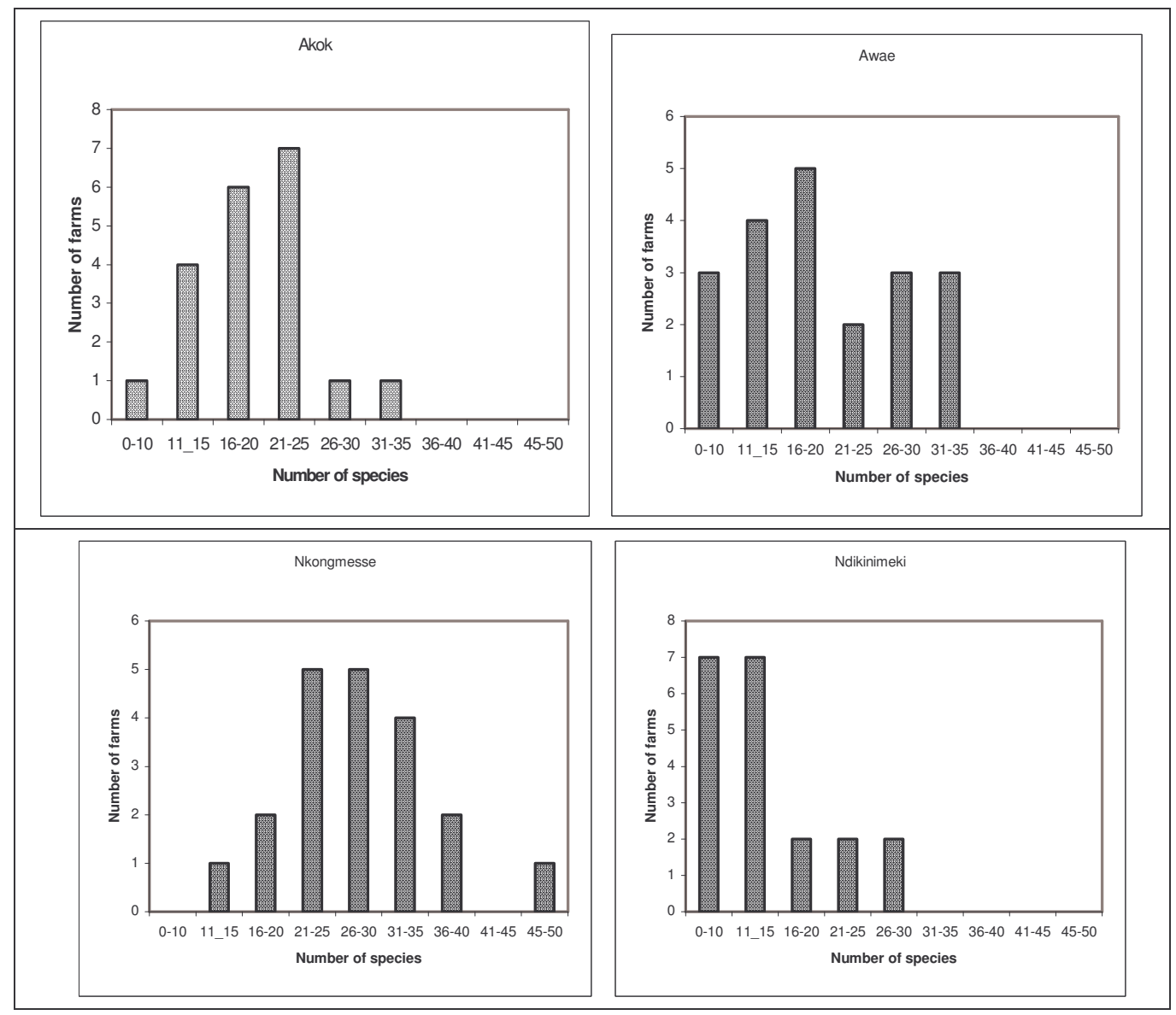

Figure 3: Distribution of the number of farms by the number of species found on them. 
Table 2 Sorensen Index (CCs) and number of shared species between locations

\begin{tabular}{lccc}
\hline CCs & Akok & Awae & Nkongmesse \\
\hline Awae & $73(\mathbf{7 0 . 8} \%)$ & & \\
Nkongmesse & $77(\mathbf{7 4 . 4 \% )}$ & $77(\mathbf{7 4 . 4 \% )}$ & \\
Ndikinimeki & $44(\mathbf{5 4 . 0 \% )}$ & $51(\mathbf{6 2 . 5 \% )}$ & $46(\mathbf{5 6 . 1 \%})$ \\
\hline
\end{tabular}

\section{DISCUSSION}

The figures of the non-cocoa tree species (165 in total) inventoried in the cocoa systems of southern Cameroon are far less than those registered from either primary or secondary forests of the area, which range from 400 to 472 species, depending on the source (Souane-Thikakul, 1985; Vivien and Faure, 1989, 1996; van Djik, 1999). Other studies (Zapfack et al., 2002) ranked cocoa systems fourth amongst the major land use systems displaying an important proportion of the trees in southern Cameroon, after the primary forest, the secondary forest and old fallows. They also noted that, despite their low diversity indices, the cocoa farms were the most protected land-use systems. Sonwa et al. (2007) recorded a total of 206 different non-cocoa indigenous and exotic tree species in the cocoa fields of the humid forest zone of the same study area. These figures, as compared to the 165 indigenous non-cocoa tree species recorded during our investigations indicate the appearance of a large proportion of exotic species, especially fruit trees in these fields. This may be attributed to the increasing demand for fruits in local and urban markets.

Species composition was more similar between the locations of Akok, Awae and Nkongmesse, in contrast, the similarities were lower between these locations and Ndikinimeki. These results were expected because the three locations, showing similarities in terms of species diversity, belong to the same eco-region, and the majority of the cocoa farms were established long before the increased population density threats to the forest domain became a reality. In addition, the communities in the three locations have almost the same elements of culture and the agricultural practices are the same as well.

In contrast Ndikinimeki, which is situated at the forest-savannah transition zone, has a different ecology, characterised by a considerable limitation in species diversity.
Moreover, farms in the area are relatively young and are generally managed by migrants mostly originating from the savannah zones of the high lands of western Cameroon, who do not usually perceive the value of tree species, as a forest dweller would do. This has led to the exertion of more influence from outsiders over the management options of these systems and subsequent negative impact on non-cocoa species diversity. They usually grow cocoa in the absence of shade and because of that, they have introduced various techniques of killing large trees with less damage to cocoa trees, while natives do not cut down the larger trees, at least not all of them. Similar cases have been reported in Ivory Coast where the strong Baoulé migrants moved from the savannah into the forest zone and determined not only the speed at which cocoa spread but also the way in which cocoa was grown (Ruf and Schroth, 2004).

Cocoa farms at Akok and Ndikinimeki locations appeared to be more homogeneous in terms of species number (standard error of 1.29 and 1.37) than Nkongmesse and Awae (standard error of 1.66 and 1.93). The farm management practices recommended by the cocoa development parastatal SODECAO, which had great influence over cocoa farmers' management options in Akok, could partly explain this. Farmers in this location reported that SODECAO agents recommended a standard typology for cocoa farms, which consisted of considerably reducing shade in farms by suppressing as many non-cocoa trees as possible and applying fertilizers, in order to optimise cocoa tree resource-use efficiency. This was not far from management techniques applied by migrants at Ndikinimeki location and discussed above. However, farmers at Akok diversely implemented the SODECAO recommendations because they were not supported with technical itineraries and material support for their application (SODECAO, 1995). 
The relatively high proportion of shared species between locations (54\% to $74 \%$ ), despite differences in ecology and land use intensity suggests that farmers in southern Cameroon have a broadly similar understanding of the role the non-cocoa tree species that they maintain play in the management of their cocoa fields. We anticipate that capturing this understanding and judiciously incorporating it into research and extension programmes may significantly contribute to develop delivery packages consistent with farmers' circumstances and aspirations, hence, increasing its adoption rate (République du Cameroun, 2005; IRAD, 2008).

An analysis of the frequency distribution of the number of species classified by the number of farms where they were found (Figure 4) on the one hand, and the distribution of farms classified by the number of species found on them (Figure 3) on the other hand, raises some concern. Indeed, despite the apparent importance of tree diversity in the cocoa systems of southern Cameroon as a whole, the proportion of farms having a high level of species diversity is low within locations. This tendency may even worsen in the years ahead due to the increasing disinterest that farmers develop towards cocoa because of a continuous decline in yields and unpredictable market prices. It is therefore feared that the tendency of introducing species of economic importance interest, mainly easily marketable fruit trees, may be at the expense of indigenous species. This concern is amplified by the fact that farmers in the study locations lack knowledge in the field of tree domestication (ICRAF, 1987; Franzel et al., 1996).

\section{Conclusion}

This study provides an insight into the status of non-cocoa indigenous tree conservation in the cocoa systems of southern Cameroon. Notwithstanding some cocoa fields, the study raises concerns about the decline of tree stock in most cocoa fields of the study locations, putting their function of seemingly permanent agriculture that preserves indigenous tree diversity to question. At present, farmers do not generally possess the technical ability to propagate seedlings of desired species and usually rely on natural regeneration. Proceeding in this manner leads to a restriction of the number of trees present, their species richness and their distribution across the farm. Yet, many forestry research institutions have developed numerous techniques for the propagation of species with potentials for domestication and inclusion in the cocoa systems of the region (Duguma et al., 1990; Okafor and Lamp, 1994; Franzel et al., 1996). This suggests a

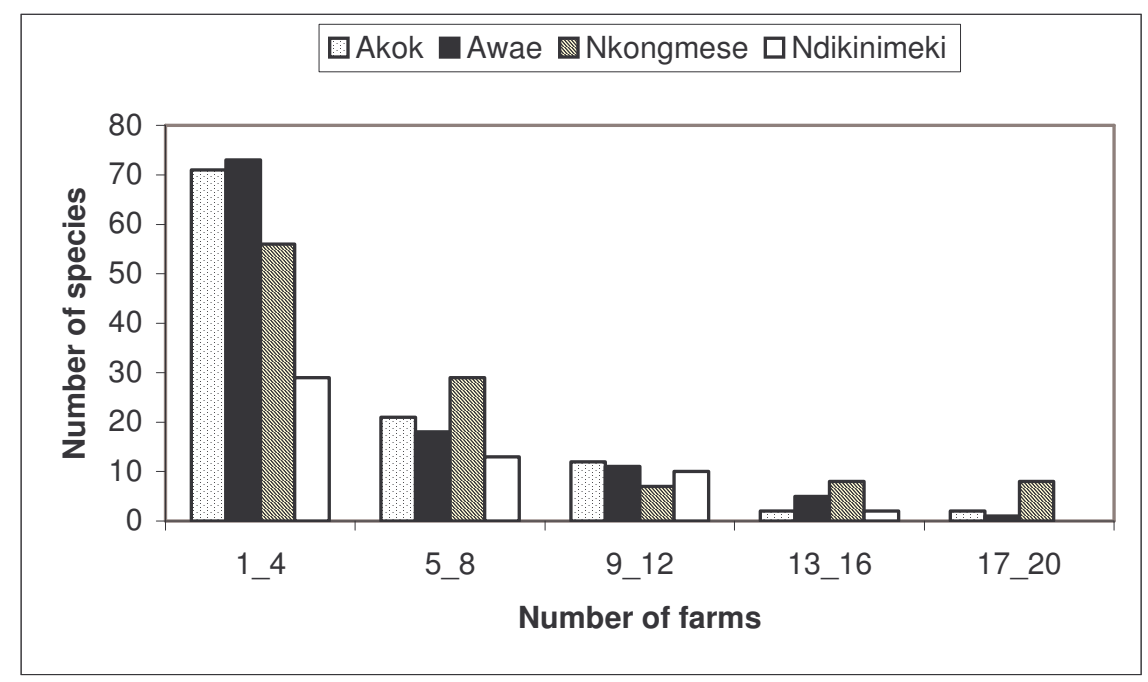

Figure 4: Frequency distribution of the number of tree species classified by the number of farm on which they were found. 
need to re-evaluate and adapt these propagation techniques to farmers' circumstances in a way to develop selfreliance amongst farmers for domestication of desired species, rather than depending on research institutions and external providers.

\section{REFERENCES}

Bidzanga Nomo. 2005. Farmers' ecological and agronomic knowledge about the management of multistrata cocoa systems in southern Cameroon. $\mathrm{PhD}$ thesis, School of Agricultural and Forest Sciences, University of Wales, Bangor, UK, p. 258.

Brower JE, Zar JH. 1977. Field and Laboratory Methods for General Ecology. Brown Publishers, Dubuque: Iowa.

Colwell RK. 1997. EstimateS: Statistical estimation of species richness and shared species from samples. Version 5. User's Guide and application published at: http://viceroy.eeb.uconn.edu/estimates.

Coulibaly O, Mbila D, Sonwa DJ, AkinAdesina, Bakala J. 2002. Responding to economic crisis in sub-Saharan Africa: New farmer-developed pest management strategies in cocoa-based plantations in southern Cameroon. Integrated Pest Management Reviews, 7: 165-172.

République du Cameroun. 2005. Document de stratégie de Développement du Secteur Rural. République du Cameroun.

Duguma B, Tonye J, Depommier D. 1990. Diagnostic Survey on Local Multipurpose Tree/Shrubs Fallow Systems, and Livestock in Southern Cameroon. ICRAF working paper No. 60. ICRAF: Nairobi, Kenya; p.34.

Duguma B, Gockowsky J, Bakala J. 2001. Smallholders cocoa (Theobroma cacao Linn) cultivation in agroforestry systems of West and Central Africa: challenges and opportunities.

Duguma B, Gockowsky J, Bakala J. 2003. Smallholder Cocoa Cultivation in Agroforestry Systems of West and Central Africa. Migratory Birds Centre; p. 21.

FAO. 1999. State of World Forest. Words and Publications: Oxford.

Franzel S, Jaenicke H, Janssen W. 1996. Choosing the Right Trees; Setting Priorities for Multipurpose Tree
Improvement. ISNAR Research Report No. 8. The Hague; International Service for National Agricultural Research; p.87.

Gillison AN, Brewer KRW. 1985. The use of gradient directed transects or gradsects in natural resource surveys. Journal of Environmental. Management, 20: 103127.

Gockowski J, Baker D, Tonye J, Weise S, Ndoumbe M, Tiki-Manga T, Fouaguegue A. 1998a. Characterization and Diagnosis of Farming Systems in the ASB Forest Margins Benchmark of Southern Cameroon. Mimeograph. IITA Humid Forest Ecoregional Centre: Yaounde; p.65.

Humbel F X. 1974. La compacité des sols ferrallitiques du Cameroun: une zonalite dans ce milieu en relation avec la desiccation saisonniere. Cah. ORSTOM, Series Pedologie, 12: 73-101.

ICRAF. 1987. Proposal for Agroforestry Research and Development in the Humid Tropical Lowlands of Cameroon. ICRAF: Nairobi, Kenya; 100p.

IRAD. 2008. Plan Stratégique de la Recherche Agricole, Horizon 2008-2012. IRAD.

Kotto-Same J, Moukam A, Njomgan R, TikiManga T, Tonye J, Diaw C, Gockowski J, Hauser S, Weise S, Nwaga D, Zapfack L, Palm C, Woomer P, Gillison A, Bignell D. Tondoh J. 2000. Alternative to Slashand-Burn. Summary report and synthesis of phase II in Cameroon.

Lebrun JP, Stork AL. 1991. Enumération des Plantes à Fleurs d'Afrique Tropicale. Généralités et Annonaceae à Pandaceae. Conservatoire et Jardins Botaniques de la Ville de Genève; 249 pp.

Lebrun JP, Stork AL. 1992. Enumération des Plantes à Fleurs d'Afrique Tropicale. Chrysobalanaceae à Apiaceae. Conservatoire et Jardins Botaniques de la Ville de Genève; 257 pp.

Lebrun JP, Stork AL. 1995. Enumération des Plantes à Fleurs d'Afrique Tropicale. Monocotiledones : Limnocharitaceae à Poaceae. Conservatoire et Jardins Botaniques de la Ville de Genève; p.341.

Lebrun JP, Stork AL. 1997. Enumération des Plantes à Fleurs d'Afrique Tropicale. Gamopétale : Clethraceae à Limiaceae. 
Conservatoire et Jardins Botaniques de la Ville de Genève; p.711.

MINAGRI. 1994. Evaluation de l'impact du PNVFA (Rapport provisoire). Yaoundé, Cameroon, Direction de l'Agriculture, p. 24

Ngobo-Nkongo MP. 2002. Ecology and Socio-Economic Importance of Short fallows in the Humid Forest Zone of Southern Cameroon. PhD thesis, School of Agricultural and Forest Sciences, University of Wales, Bangor, UK, p.268.

Okafor JC, Lamb A. 1994. Fruit trees: diversity and conservation strategies. In Tropical Trees; Potential for Domestication, Rebuilding Genetic Resources, Leakey RRB, Newton A (eds). HMSO: London.

Ruf F, Schroth G. 2004. Chocolate forests and monoculture: a historical review of cocoa growing and its conflicting role in tropical deforestation and forest conservation. In Agroforestry and Biodiversity Conservation in Tropical landscape, Schroth et al. (eds). Island Press; 107-134.

Saunders K. 2002. Farmers' knowledge of trees for shade within cocoa farms in Atwima District, Ghana. M.Sc thesis in Environmental Forestry, University of Wales, Bangor, 83 pp.

SODECAO. 1995. Bilan du processus de prise en charge par les groupements de producteurs de la commercialisation $d u$ cacao. Direction des Programmes Agricoles: Yaoundé.
Sonwa D, Ousmane-Coulibali, AkinwumiAdesina A, Weise SF, Tchatat M. 2004. Integrated pest management in cocoa agroforests in southern Cameroon: Constraints and overview. Intergrated Pest Management Reviews, 7: 191-199.

Sonwa D, Nkonmeneck BA, Weise SF, Tchatat M, Akin A Adesina. 2007. Diversity of plants in cocoa agroforests in the humid forest zone of southern Cameroon. Biodivers. Conserv., 16: 2385-2400.

Souane-Thikakul, 1985. Manual of Dendrology. Cameroon National Centre for Forestry Development and Canadian International Development Agency; p.638.

van Djik JFW. 1995. The abundance and ditribution of non-timber forest products in the Bipindi-Akom II region, South Cameroon. Intermediate report. The Tropenbos-Cameroon Programme, Kribi, Cameroon.

van Ranst E. 1983. Land evaluation of tropical soils. Polycopié, Centre Universitaire de Dschang, Cameroon.

Vivien J, Faure JJ. 1996. Fruitiers Sauvages d'Afrique. Les Espèces du Cameroun. Coopération Française et CTA.

Vivien J, Faure JJ. 1989. Arbres des Forets Denses d'Afrique Centrale. Especes du Cameroun. Republique Francaise.

Zapfack L, Engwald S, Sonke B, Achoundong G, Birang AM. 2002. The impact of land conversion on plant biodiversity in the forest zone of Cameroon. Biodiversity and Conservation, 2: 2047-2061. 